\title{
Tomato Cultivars for Production in Florida ${ }^{1}$
}

\section{G. McAvoy ${ }^{2}$}

This list includes a number of varieties of tomatoes currently popular with Florida growers, it is by no means a comprehensive list of all varieties that may be adapted to the state. At present 4-5 cultivars probably constitute $80-90 \%$ of commercial production in Florida.

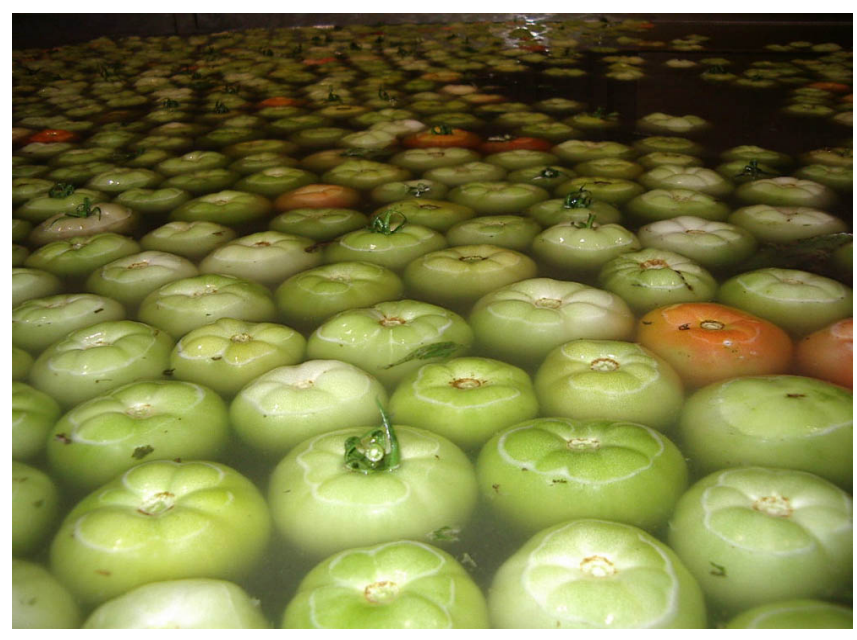

Figure 1. Harvested tomatoes in wash tank. Credits: Monica Ozores-Hampton

\section{Round Tomatoes}

(See Table 1 for Key to Abbreviations.)
Amelia - Main season. Resistance to F-R 1,2,3, $\mathrm{N}, \mathrm{V} 1$, intermediate resistance to Stemph and TSWV. Vigorous determinate plant with an excellent leaf canopy ideal for green and vine ripe harvest, crack tolerant skin. Firm, aromatic fruit. Harris Moran.

Bella Rosa - Resistant to TSWV. Determinate type. Heat tolerant. Produces firm, uniformly shaped fruit. Sakata.

BHN 444 - Midseason. Resistance to F-R 1,2, TSWV, V1. Large to extra-large, globe shaped fruit. Determinate bush with good cover. High yields, good firmness, good flavor. Pruning not required. BHN Seed.

BHN 586 - Midseason. Resistance to FCR, F-R 1,2, N, V1. Large to extra-large, deep globe shaped fruit. Determinate, medium to tall vine. Large, firm, uniform green fruits are well suited for mature green or vine-ripe production. BHN Seed.

BHN 640 - Midseason. Resistance to F-R 1,2, TSWV, V1, F-R 3 tolerance. Large to extra-large, globe fruit with uniform green shoulders. Determinate bush with good cover. BHN Seed.

Crista - 74 days, Resistance to, F-R 1,2,3, N, intermediate TSWV, V1. Large, deep globe fruit, tall

1. This document is IPM-203 (IN756), one of a series from the Grower's IPM Guide for Florida Tomato and Pepper Production by the Entomology and Nematology Department, Florida Cooperative Extension Service, Institute of Food and Agricultural Sciences, University of Florida. Published: December 2007. Please visit the EDIS Website at http://edis.ifas.ufl.edu.

2. G. McAvoy, county extension director and regional vegetable extension agent, Institute of Food and Agricultural Sciences, University of Florida.

The Institute of Food and Agricultural Sciences (IFAS) is an Equal Opportunity Institution authorized to provide research, educational information and other services only to individuals and institutions that function with non-discrimination with respect to race, creed, color, religion, age, disability, sex, sexual orientation, marital status, national origin, political opinions or affiliations. U.S. Department of Agriculture, Cooperative Extension Service, University of Florida, IFAS, Florida A. \& M. University Cooperative Extension Program, and Boards of County Commissioners Cooperating. Larry Arrington, Dean 
robust plants. Does best with high fertility and pruned to three leaders. Good flavor, color and shelf-life. Harris Moran.

Crown Jewel - Resistance to ASC, FCR, F-R 1,2 , Stemph and V1. Determinate with medium-tall bush. Uniform fruit have a deep oblate shape and good firmness and quality with uniformly-colored shoulders and jointed pedicles. Seminis.

FL 47 - Midseason. Resistance to ASC, F-R 1,2, Stemph, V1. Very large, deep oblate fruit. Determinate, medium size bush. Very firm, smooth, uniform green fruits are adaptable to both mature-green and vine-ripe harvest. Seminis.

FL 91 - Midseason. Resistance to ASC, F-R 1,2, Stemph, V1. Large, deep, oblate firm fruit with uniform green shoulders. Strong, determinate vine with heat-set capabilities. Heavy early yield with high packout. Seminis.

HA 3073 - Midseason. Resistance to F-R 2,3, V1, TYLCV. High quality, medium size globe shaped fruit. Consistently high yielding. Hazera.

Linda - Main season. Resistance to ASC, F-R1, 2, Stemph, V1. Large, round fruit with excellent firmness, sturdy, determinate bush with good cover. Competitive yields of large, smooth, uniform shouldered fruit with a small blossom end scar. Sakata.

Phoenix - Early midseason. Resistance to ASC, F-R 1,2, Stemph and V1. Hot-set tomato.

Determinate, vigorous vine with good leaf cover for fruit protection. Large to extra-large, high quality, firm, globe-shaped fruit are uniformly-colored with jointed pedicles. Seminis.

Quincy - Full season. Resistance to ASC, F-R 1,2, Stemph, TSWV and V1. Tall determinate plant. Large and extra-large fruit with a deep oblate shape fruit are firm and uniformly colored with excellent quality. Seminis.

RPT 6153 - 77 days. Resistance to, F-R 1,2, Stemph and V1. Large, vigorous bush. Good eating quality and fancy appearance in a large sturdy shipping tomato. Firm enough for vine-ripe but it also gasses. Seedway.
Sebring - Main season. Resistance to FCR, F-R 1,2,3, Stemph and V1. Medium to tall determinate, bush. Extra-large to large, smooth, deep oblate fruit with uniform green shoulders, tight blossom ends. Outstanding yield potential. Seminis.

Solar Fire - 73 days. Resistance to F-R 1,2 3, Stemph and V1. Medium, compact vines don't require pruning. Large, flat, round, firm fruit. Sets well in heat. Tends to be free of fruit disorders. Harris Moran.

Soraya - 80 days. Resistance to FCR, F-R 1,2,3, Stemph and V1. Strong, large bush. High quality, very smooth beefsteak, typically producing large and extra-large fruit. Continuous set. Syngenta Rogers Seed

Talledega - Midseason. Resistance to F-R 1,2, Stemph, TSWV and V1. Determinate bush for stake culture. Large to extra large globe to deep globe shaped fruit. High resistance to TSWV. Some heat setting ability. Performs well with light to medium pruning. Syngenta Rogers Seed.

Tygress - Main season. Resistance to ASC, F-R 1,2, Stemph, ToMV, TYLCV and V1. Deep oblate, smooth, uniform high quality fruit. Vigorous, determinate plant. High yield potential. Seminis.

\section{Roma Tomatoes}

(See Table 1 for Key to Abbreviations.)

BHN 410 - 73 days. Resistance to BSK, F-R 1,2, Stemph and V1. Compact to small bush. Concentrated high yield. Large smooth blocky fruit tolerant to weather cracking. Jointless. BHN Seed.

BHN 411 - 73 days. Resistance to BSK, F-R 1,2, Stemph and V1. Compact plant. Concentrated set. Large smooth fruit is tolerant to weather cracks and has reduced tendency for greywall. Jointless. BHN Seed.

BHN 685 - Midseason. Resistance to F-R 1,2,3, TSWV and V1. Determinate, vigorous bush Large to extra-large, deep blocky globe shaped fruit. Pruning not recommended. BHN Seed.

Marianna - 74 days. Resistance to ASC, F-R 1,2, N and V1 and tolerant to Stemph. Determinate, 
small to medium sized plant with exceptional fruit set. Fruit are predominately extra large and extremely uniform in shape. Fruit wall is thick and external and internal fruit color is very good with excellent firmness and shelf life. Sakata.

Monica - Midseason. Resistance to BSK. F-R 1,2, Stemph and V1. Vigorous bush with good cover. High percentage of firm extra large, elongated fruit. Jointed pedicel and uniform green fruit color. Sakata.

Sunoma - Main season. Resistance to BSK, F-R 1,2, N, Stemp, TOMV and V1. Determinate with good fruit cover. Medium-large, elongated cylindrical fruit maintains fruit size through multiple harvests. Widely adapted. Seminis.

\section{Cherry Tomatoes}

(See Table 1 for Key to Abbreviations.)

BHN 268 - Early. Resistance to F-R 1, V1. Determinate, small to medium bush. High yields. An extra firm cherry tomato that holds, packs and ships well. BHN Seed.

Camelia - Midseason. Resistance to F-R 1, TMV, V1. Indeterminate bush. Deep globe, cocktail-cherry size with excellent firmness and long shelf life. Outdoor or greenhouse production. Siegers Seed.

Cherry Blossom - 70 days. Resistance to ASC, BSK, F-R 1,2, N, Stemph, V1. Determinate type. Large cherries, holds and yields well. Seedway.

Super Sweet 100 VF- 65 days. Resistance to F-R 1, V1. Indeterminate vine. Produces large clusters of round uniform fruit with high sugar levels. High yield potential. Siegers Seed. Seedway.

Shiren - Resistance to F-R 1, 2, V1, N, ToMV. Compact plant with high yield potential and nice cluster. Hazera.

\section{Grape Tomatoes}

(See Table 1 for Key to Abbreviations.)

Brixmore - Very early. Resistance to N, ToMV, V1. Indeterminate. Very uniform in shape and size, deep glossy red color with very high early and total yield. High brix, excellent firm flavor. Harris Moran.

Cupid - 59 days. Resistance to ASC, F-R 1,2, and Stemph. Intermediate resistance to BSK. Vigorous, indeterminate bush. Oval-shaped fruit have an excellent red color and a sweet flavor. Seminis.

Jolly Elf - Early season. Resistance to F-R 2, V1 and cracking. Determinate plant. Extended market life with firm, flavorful grape-shaped fruits. Average 10\% brix. Siegers Seed, Seedway.

Santa - 75 days. Resistance to F-R 1, N, TMV and V1. Vigorous indeterminate bush. Firm elongated grape shaped fruit with outstanding in flavor and up to 50 fruits per truss. Thompson and Morgan.

St. Nick - Mid-Early season. Indeterminate bush. Oblong, grape-shaped fruit with brilliant red color and fantastic flavor. Up to $10 \%$ brix. Siegers Seed.

Smarty - 69 days. Vigorous, indeterminate bush with short internodes. Plants are $25 \%$ shorter plant than Santa. Good flavor, sweet and excellent red color. Seedway.

Sweet Hearts - Early season. Resistance to CLS, F-R 1, ToMV. Indeterminate plants with continuous sets and full clusters to the top of the plant. Brilliant red color, very uniform, excellent flavor, good resistance to cracking. High brix, excellent shelf-life. Sakata.

Tami $\mathbf{G}-60$ days. Vigorous, indeterminate bush picks for an extended period. Very sweet, firm, fruit. Yields well. Seedway. 
Table 1. Key to Abbreviations

\begin{tabular}{|c|c|}
\hline ASC & $\begin{array}{l}\text { Alternaria stem canker - Alternaria } \\
\text { alternata f.sp. lycopersici }\end{array}$ \\
\hline BSK & $\begin{array}{l}\text { Bacterial speck - Pseudomonas } \\
\text { syringae pv tomato race } 0\end{array}$ \\
\hline CLS & $\begin{array}{l}\text { Cladosporium leaf mold - Cladosporium } \\
\text { fulvum }\end{array}$ \\
\hline F-R $1,2,3$ & $\begin{array}{l}\text { Fusarium wilt Race 1, 2,3 - Fusarium } \\
\text { oxysporum f.sp. lycopersici races } 1,2,3\end{array}$ \\
\hline FCR & $\begin{array}{l}\text { Fusarium crown rot - Fusarium } \\
\text { oxysporum f.sp.radicis-lycopersici) }\end{array}$ \\
\hline $\mathrm{N}$ & $\begin{array}{l}\text { Root knot nematode - Meloidogyne } \\
\text { arenaria, M. incognita \& M. javanica }\end{array}$ \\
\hline Stemph & Gray leaf spot - Stemphylium solani \\
\hline TMV & Tobacco mosaic virus \\
\hline ToMV & Tomato mosaic virus \\
\hline TSWV & Tomato spotted wilt virus \\
\hline TYLCV & Tomato yellow leaf curl virus \\
\hline V1 & $\begin{array}{l}\text { Verticillium wilt - Verticillium albo-atrom, } \\
\text { Verticillium dahliae race } 1\end{array}$ \\
\hline $\mathrm{R}$ & Resistant \\
\hline IR & Intermediate Resistance \\
\hline $\mathrm{T}$ & Tolerant \\
\hline
\end{tabular}

